\title{
НЕИТРОННО-АКТИВАЦИОННЫИ АНАЛИЗ ФОСФОРИТОВ, ПРОДУКТОВ ИХ ОБОГАЩЕНИЯ И КОНЦЕНТРАТА ГЛАУКОНИТА
}

L. PELEKIS. O. KIRRET, I. TAURE, Zane PELEKIS, G. EGLIT, E. RAJAVEE, V. AHELIK. FOS. FORIITIDE, NENDE RIKASTUSPRODUKTIDE JA GLAUKONIIDI KONTSENTRAADI NEUTRONAKTIVATSIOONIANALOOS

$\mid \overline{\text { L. PELEKIS| }}$, O. KIRRET, I. TAURE, Zane PELEKIS, G. EGLIT, E. RAJAVVEE, V. AHELIK. NEUTRON ACTIVATION ANALYSIS OF PHOSPHORITES, THEIR ENRICHMENT PRODUCTS AND CONCENTRATE OF GLAUCONITE

Макрохимический состав фосфоритов перспективных месторождений ЭССР изучен довольно детально благодаря массовым исследованиям $\left[{ }^{1-4}\right]$. Информация же об их микроэлементном составе весьма ограничена ${ }^{[5-8}$. В связи с этим нами был проведен нейтронно-активационный анализ фосфоритных руд, продуктов их обогащения и концентрата глауконита с тем, чтобы выяснить и уточнить содержания в них макро- и микроэлементов, а также следовых количеств примесей. Все исследования были проведены на установке при ядерном реакторе Института физики АН ЛатвССР, условия и режимы описаны в $\left[{ }^{9}, 10\right]$.

В нашем распоряжении было девять технологических проб, из них три $(1,2$ и 9), представленные фосфоритами и глауконитом, получены из фонда бывшего сектора обогатительных процессов Института химии АН ЭССР, остальные шесть $(3-8)$ - из Управления геологии ЭССР.

В табл. 1 приведены результаты анализа фосфоритных руд и продуктов их обогащения на содержание основных макрокомпонентов. В табл. 2 охарактеризовано содержание 29 элементов (макро- и микроэлементов, а также элементов-следов) в фосфоритных рудах, продуктах их обогащения и концентрате глауконита. Кроме основного макрокомпонента - кальция, фосфориты содержат в значительных количествах стронций и барий, а также в малых количествах лантан, церий, самарий, тербий и иттербий.

Таблица 1

Химический состав фосфоритов и продуктов их обогащения *

\begin{tabular}{l|l|r|r|r|r|r|r}
\hline \multirow{2}{*}{ Проба } & \multirow{2}{*}{ Продукт } & \multicolumn{5}{|c}{ Содержание, \% } \\
\cline { 3 - 7 } & & н. о. & $\mathrm{P}_{2} \mathrm{O}_{5}$ & $\mathrm{MgO}$ & $\mathrm{Fe}_{2} \mathrm{O}_{3}$ & $\mathrm{FeS}_{2}$ & \multirow{2}{*}{$\mathrm{CaO}$} \\
\hline ПТ-125 & концентрат & 12,75 & 31,56 & 0,38 & 1,71 & 1,71 & 50,10 \\
ПТ-125 & руда & 74,70 & 9,14 & 0,18 & 1,02 & 0,68 & 33,13 \\
ПТ-157 & шламы & 31,17 & 18,20 & 2,02 & 3,77 & 0,14 & 31,58 \\
ПТ-157 & концентрат & 7,86 & 29,40 & 2,03 & 1,89 & 0,23 & 44,83 \\
ПТ-157 & хвосты & 95,50 & 0,77 & 0,05 & 0,50 & 0,06 & 1,66 \\
ПТ-157 & руда & 53,78 & 13,70 & 1,17 & 1,28 & 0,15 & 22,33
\end{tabular}

* Анализы сделаны С. Детковским. 


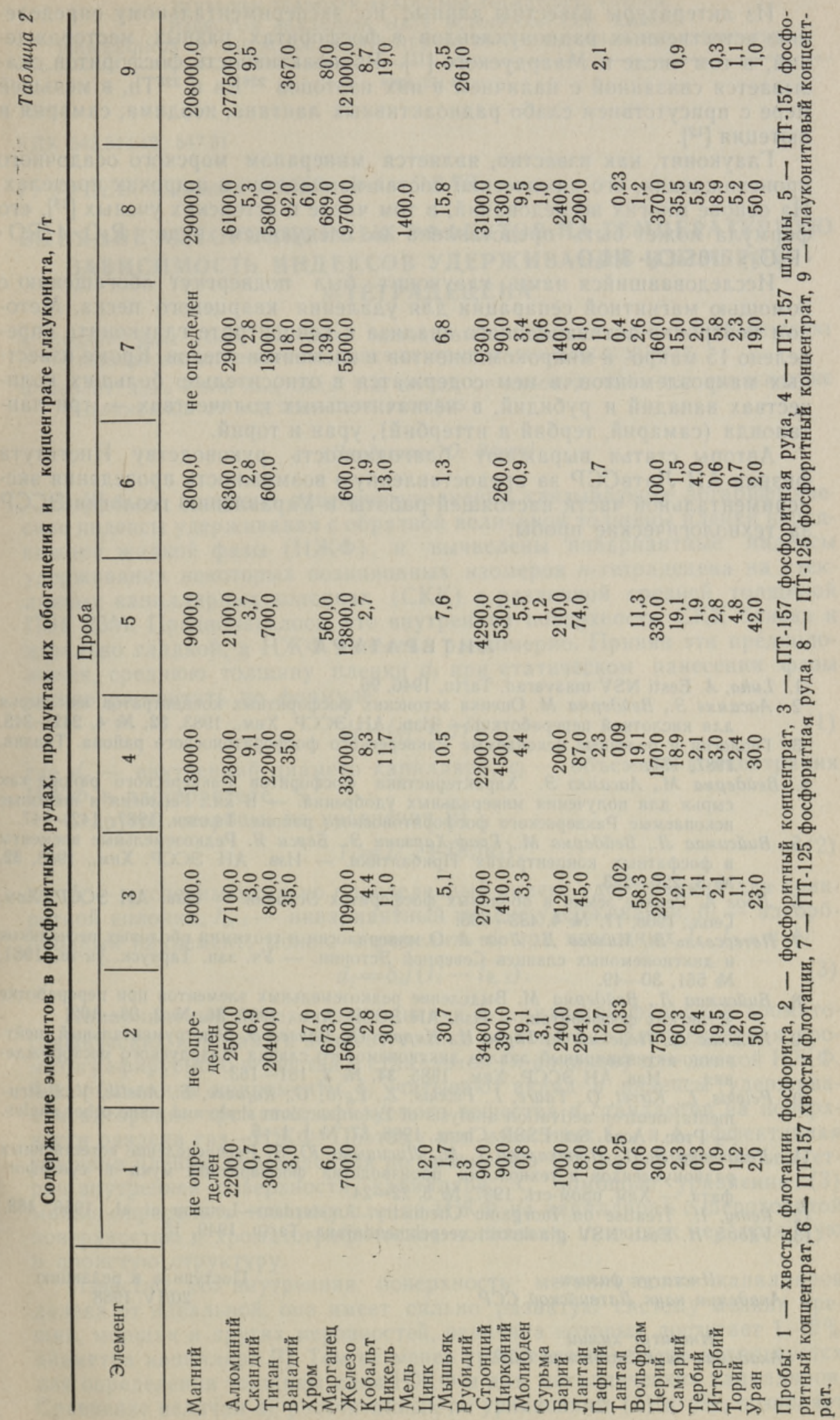


Из литературы известны данные по экспериментальному определению естественных радионуклеидов в фосфоритах разных месторождений, в том числе и Маардуского [ $\left.{ }^{11}\right]$. Радиоактивность фосфоритов оказывается связанной с наличием в них изотопов ${ }^{226} \mathrm{Ra}$ и ${ }^{228} \mathrm{Th}$, в меньшей мере с присутствием слабо радиоактивных лантана, неодима, самария и лютеция $\left[{ }^{12}\right]$.

Глауконит, как известно, является минералом морского осадочного происхождения, его химический состав изменяется в широких пределах. На основе многих исследований, в том числе и эстонских ученых $\left[{ }^{13}\right]$, его формула может быть представлена в следующем виде: $\mathrm{R}_{2} \mathrm{O} \cdot 4(\mathrm{RO}$. $\left.\cdot \mathrm{R}_{2} \mathrm{O}_{3}\right) \cdot 10 \mathrm{SiO}_{2} \cdot 3 \mathrm{H}_{2} \mathrm{O}$.

Исследовавшийся нами глауконит был подвергнут обогащению с помощью магнитной сепарации для удаления кварцевого песка. Методом нейтронно-активационного анализа в концентрате глауконита определено 15 макро- и микрокомпонентов и элементов-следов. Кроме известных макроэлементов, в нем содержатся в относительно больших количествах ванадий и рубидий, в незначительных количествах - три лантаноида (самарий, тербий и иттербий), уран и торий.

Авторы статьи выражают благодарность руководству Института физики АН ЛатвССР за предоставленную возможность проведения экспериментальной части настоящей работы и Управлению геологии ЭССР за технологические пробы.

\section{Л И ТЕРА Т У РА}

1. Luha, A. Eesti NSV maavarad. Tartu, 1946, 96.

2. Аасамяэ Э., Вейдерма М. Оценка эстонских фосфоритных концентратов как сырья для кислотной переработки. - Изв. АН ЭССР. Хим., 1983, 32, № 4, 242-245.

3. Геология и полезные ископаемые Раквереского фосфоритоносного района. Таллин, $1987,137$.

4. Вейдерма М., Аасамяэ Э. Характеристика фосфоритов Раквереского района как сырья для получения минеральных удобрений. - В кн.: Геология и полезные ископаемые Раквереского фосфоритоносного района. Таллин, 1987, 142-147.

5. Вийсимаа Л., Вейдерма М., Граф-Харзани Э., Берси Я. Редкоземельные элементы в фосфатных концентратах Прибалтики. - Изв. АН ЭССР. Хим., 1983, 32, № $3,220-223$.

6. Лоог А. Редкие земли в оболовых фосфоритах Эстонии. - Изв. АН ЭССР. Хим. Геол., 1968, 17, № 4, 433-435.

7. Петерселль В., Михеев Д., Лоог А. О минералогии и геохимии оболовых песчаников и диктионемовых сланцев Северной Эстонии. - Уч. зап. Тартуск. ун-та, 1981, № $561,30-49$.

8. Вийсимаа Л., Вейдерма М. Выделение редкоземельных элементов при переработке эстонских фосфоритов. - Изв. АН ЭССР. Хим., 1987, 36, № 2, 98-102.

9. Пелекис Л., Пелекис З., Тауре И., Киррет О., Раявее Э. Инструментальный нейтронно-активационный анализ диктионемового сланца Маардуского месторождения. - Изв. АН ЭССР. Хим., 1985, 34, № 3, 161-163.

10. Pelekis, L., Kirret, O., Taure, I., Pelekis, Z., Eglit, G., Rajavee, E., Ahelik, V. Instrumental neutron activation analysis of Estonian alum shale and some other shales. - Proc. Acad. Sci. ESSR. Chem., 1988, 37, № 1, 1-5.

11. Лисаченко Э. П., Поникарова Т. М., Лисицына Ю. З. Распределение естественных радионуклендов и технологии производства фосфоритной муки и суперфосфата. - Хим. пром-сть, 1987, № 5, 22-24.

12. Remy, $H$. Treatise on Inorganic Chemistry. Amsterdam-London et al., 1956, 488.

13. Vilbok, $H$. Eesti NSV glaukoniit veepehmendajana. Tartu, 1949, 15.

Ннститут физики

Академии наук Латвийской ССР

Ннститут химии

Академии наук Эстонской ССР
Поступила в редакцию 20/IV 1988 